\title{
Analisa Tingkat Keberhasilan Inseminasi Buatan (IB) pada Sapi Potong Ditinjau dari BCS (Body Condition Score) Di Kecamatan Bungah Kabupaten Gresik Jawa Timur
}

\section{Analysis Stage Artificial Insemination Succes on Cattle Beef Seen from BCS (Body Condition Score) in Bungah Gresik Jawa Timur}

\author{
Firmansyah $^{1}$, Ir. Arif Arya Hertanto, M.MA ${ }^{2}$, Ir. Hj. Nuril Badriyah, M.M ${ }^{3}$ \\ ${ }^{1}$ Mahasiswa Fakultas Peternakan \\ ${ }^{2}$ Dosen Pembimbing Utama \\ ${ }^{3}$ Dosen Pembimbing Pendamping \\ Program Studi Peternakan \\ Fakultas Peternakan, Universitas Islam Lamongan (UNISLA)
}

\begin{abstract}
RINGKASAN
Pengumpulan data penelitian dilaksanakan pada tanggal 1 Mei - 30 Juni tahun 2016 di kecamatan Bungah kabupaten Gresik provinsi Jawa Timur. Tujuan penelitian ini adalah untuk mengetahui apakah tingkat BCS (Body Condition Score) berpengaruh terhadap tingkat keberhasilan inseminasi buatan (IB) pada sapi potong. Metode penelitian yang digunakan adalah metode survey dan menggunakan metode kualitatif, metode kualitatif adalah metode penelitian yang digunakan untuk meneliti pada kondisi obyek yang alamiah, dimana peneliti sebagai instrumen kunci, teknik pengumpulan data dilakukan secara triangulasi (gabungan), analisis data bersifat induktif, dan hasil penelitian kualitatif lebih menekankan makna dari pada generalisasi (Sugiyono, 2013). Data sampel yang digunakan dalam penelitian ini sejumlah 30 ekor sapi potong. Hasil penelitian menunjukkan bahwa 30 ekor sapi dengan tingkat nilai BCS (Body Condition Score) yang berbeda yakni BCS $1=1$ ekor, BCS $2=12$ ekor, BCS $3=11$ ekor, BCS $4=6$ ekor dimana BCS dilambangkan dengan variable $Y, \Sigma Y=82$ sedangkan keberhasilan ib dilambangkan dengan variabel $X, \Sigma X=56$ terdiri dari 26 bunting dan 4 tidak bunting dimana bunting dilambangkan dengan $\mathrm{B}$ yang memiliki nilai $=2$ sedangkan tidak bunting dilambangkan dengan TB yang memiliki nilai $=1$. Hasil perhitungan dengan rumus person product moment nilai $r$ (korelasi) $=0,10585$ kemudian diuji menggunakan tabel $\mathrm{t}=\mathrm{dk}=\mathrm{n}-2=30-2=28, \alpha=0,05, \mathrm{t}$ tabel $=2,763(-2,763-2,763)$ nilai mendekati 0 yang artinya diterima dan memiliki korelasi yang sangat lemah atau tidak berkorlasi.
\end{abstract}

\section{ABSTRACT}

Research data collection was held on 1 Mey to 30 June 2016 in Bungah Gresik Jawa Timur. The purpose of this research is knowing what BCS (Body Condition Score) rate have relation with the Artificial Insemination success on beef cattle. Research methods used survey methods and using kualitatif methods which used for research on natural object condition where researcher as keys instrument, technic data accumulation do it with triangulation, analysis data apoplectic is induktif and result research kualitatif more to advertise sense over generalitation (Sugiyono, 2013). Data sample which used in research is amount 30 cattle beef. Result research to show assumed 30 cattle beef with stage rate grade BCS (Body Condition Score) which different is BCS $1=1$ tail, BCS $2=12$ tail, BCS $3=11$ tail, BCS $4=$ 6 tail Where BCS with symbol Y variable, $\Sigma \mathrm{Y}=82$ then AI success with symbol $\mathrm{X}$ variable, $\Sigma \mathrm{X}=56$ which 26 pregnant and 4 not pregnant which pregnant with symbol B have grade $=2$ when not pregnant with symbol TB have grade $=1$. Result calculation with person product moment formula grade $r$ (correlation) $=0,10585$ then used $\mathrm{t}$ table $=\mathrm{dk}=\mathrm{n}-2=30-2=28, \alpha=0,05, \mathrm{t}$ table $=2,763(-2,763-$ 2,763 ) grade to accost 0 its means acceptable and have exceptional correlation or nothing correlation.

Key words : BCS (Body Condition Score), Artificial Insemination

\section{PENDAHULUAN}

Salah satu upaya untuk meningkatkan kesehatan dan kecerdasan masyarakat Indonesia adalah dengan meningkatkan konsumsi protein hewani yang telah diketahui secara luas memiliki kandungan asam amino esensial dengan komposisi seimbang. Upaya meningkatkan konsumsi protein hewani bagi masyarakat berarti juga harus meningkatkan 
produksi bahan pangan asal ternak. Pada akhirnya, hal tersebut berarti upaya peningkatan produksi ternak.

Produk utama peternakan sapi potong adalah daging, baik berupa anak-anak sapi yang dilahirkan maupun sapi hasil pembesaran dan penggemukan. Tinggi rendahnya produktivitas tersebut dipengaruhi oleh faktor genetik ternak itu sendiri dan faktor lingkungan.Faktor genetik yang diturunkan oleh keturunan pejantan dan induknya. Apabila mutu genetik dari kedua tetuanya tinggi maka dapat diharapkan keturunannya juga bermutu genetis tinggi. Faktor ini meliputi iklim, penyakit dan manjemen (penanganan) terhadap ternak itu sendiri. Keduanya (faktor genetis dan lingkungan) harus diperhatikan dengan sungguhsungguh agar diperoleh keuntungan yang optimal dalam peternakan sapi potong (Rianto dan Purbowati, 2010).

Indonesia dengan jumlah penduduk diatas 230 juta jiwa juga membutuhkan pasokan daging sapi dalam jumlah besar. Sejauh ini, peternakan domestik belum mampu memenuhi permintaan daging dalam negeri. Timpangnya antara pasokan dan permintaan ternyata masih tinggi. Tidak mengherankan jika lembaga yang memiliki otoritas tertinggi dalam hal pertanian termasuk peternakan. Departemen Pertanian mengakui masalah utama usaha sapi potong di Indonesia terletak pada suplai yang selalu mengalami kekurangan setiap tahunnya. Sementara laju pertunbuhan konsumsi dan pertambahan penduduk tidak mampu diimbangi oleh laju peningkatan populasi sapi potong. Pada gilirannya, kondisi seperti ini memaksa Indonesia untuk selalu melakuan impor, baik dalam bentuk sapi maupun dalam bentuk daging dan jeroan sapi (Rianto dan Purbowati, 2010)

Pemuliaan adalah merupakan suatu usaha untuk memperbaiki atau meningkatkan mutu genetik ternak melalui pengembangbiakan ternak-ternak yang memiliki potensi genetik yang baik sehingga diperoleh kinerja atau potensi produksi yang diharapkan.Sedangkan arti pembibitan adalah suatu tindakan peternak untuk menghasilkan ternak bibit, dimana yang dimaksud dengan temak bibit adalah ternak yang memenuhi persyaratan dan karakter tertentu untuk dikembangbiakan dengan tujuan standar produksi/kinerja yang ditentukan, karena itu untuk memenuhi kebutuhan konsumsi daging yang dibutuhkan oleh masyarakat yang semakin lama semakin meningkat tersebut yaitu diantaranya dengan cara meningkatkan reproduksi ternak sapi betina.

Penelitian ini dilakukan di Kecamatan Bungah Kabupaten Gresik. Dalam penelitian yang berjudul Analisa Tingkat Keberhasilan Inseminasi Buatan (IB) Pada Sapi Potong Di Tinjau Dari BCS (Body Condition Score) di Kecamatan Bungah, yang diharapkan dapat diketahui apakah BCS (Body Condition Score) berpengaruh terhadap keberhasilan Inseminasi Buatan (IB) pada sapi potong.

\section{METODE PENELITIAN}

Metode yang digunakan dalam penelitian ini adalah dengan cara survey dan menggunakan metode kualitatif, metode kualitatif adalah metode penelitian yang digunakan untuk meneliti pada kondisi obyek yang alamiah, dimana peneliti sebagai instrumen kunci, teknik pengumpulan data dilakukan secara triangulasi (gabungan), analisis data bersifat induktif, dan hasil penelitian kualitatif lebih menekankan makna dari pada generalisasi (Sugiyono, 2013). Karena itu dalam penelitian ini peneliti disamping mengambil data secara langsung juga sebagai penilai tingkat BCS dan juga sebagai Inseminator IB.

\section{VARIABEL PENGAMATAN}

- Variabel bebas : tingkat BCS (Body Condition Score) sapi dan jumlah sapi yang berhasil di inseminasi/bunting.

- Varabel terikat : Tingkat keberhasilan IB/NRR (Non Return Rate).

\section{Rumus Pearson Product Moment}

Koefisien Korelasi Sederhana disebut juga dengan Koefisien Korelasi Pearson karena rumus perhitungan Koefisien korelasi sederhana ini dikemukakan oleh Karl Pearson yaitu seorang ahli Matematika yang berasal dari Inggris. Rumus yang dipergunakan untuk menghitung Koefisien Korelasi Sederhana adalah dengan rumus Pearson Product Moment 


$$
r=\frac{n \Sigma x y-(\Sigma x)(\Sigma y)}{\sqrt{\left\{n \Sigma x^{2}(\Sigma x)^{2}\right\}\left\{\left(n \Sigma y^{2}\right)(\Sigma y)^{2}\right\}}}
$$

\section{d. Dimana :}

$\mathrm{N}=$ Banyaknya Pasangan data $\mathrm{X}$ dan $\mathrm{Y}$

$\Sigma \mathrm{x}=$ Total Jumlah dari Variabel $\mathrm{X}$

$\Sigma \mathrm{y} \quad=$ Total Jumlah dari Variabel Y

$\Sigma \mathrm{x}^{2}=$ Kuadrat dari Total Jumlah Variabel

$\mathrm{X}$

$\Sigma \mathrm{y}^{2}=$ Kuadrat dari Total Jumlah Variabel

$\mathrm{Y}$

$\Sigma x y=$ Hasil Perkalian dari Total Jumlah

Variabel X dan Variabel Y

Kemudian dilakukan Uji t Parsial. Rumus Hitung Uji t Parsial :

$$
t=r \sqrt{\frac{n-2}{1-r^{2}}}
$$

Dimana :

$$
\begin{aligned}
& \mathrm{r}=\text { korelasi } \\
& \mathrm{n}=\text { jumlah Akseptor }
\end{aligned}
$$

HASIL DAN PEMBAHASAN

Data Hasil Penelitian Tentang Nilai BCS (Body Condition Score) dan Keberhasilan IB Pada Sapi Potong

Dibawah ini disajikan data tentang tingkat BCS (Body Condition Score) dan jumlah keberhasilan Inseminasi Buatan (IB) yang terjadi pada saat penelitian.

Tabel 2. Data nilai BCS dan keberhasilan IB

\begin{tabular}{|l|l|l|l|l|}
\hline & Nilai & & \multicolumn{2}{|l|}{ Keberhasilan IB (X) } \\
\cline { 4 - 5 } & $\begin{array}{l}\text { BCS } \\
(Y)\end{array}$ & Jumlah & Bunting & $\begin{array}{l}\text { Tidak } \\
\text { Bunting }\end{array}$ \\
\hline 1 & 1 & 1 & 1 & 0 \\
\hline 2 & 2 & 12 & 11 & 1 \\
\hline 3 & 3 & 11 & 11 & 0 \\
\hline 4 & 4 & 6 & 3 & 3 \\
\hline 5 & 5 & 0 & 0 & 0 \\
\hline
\end{tabular}

Sumber data Akseptor di Inseminator kecamatan Bungah (2016)

Data tentang hasil penelitian tentang nilai BCS (Body Condition Score) dan keberhasilan IB (Inseminasi Buatan) pada sapi potong akan disajikan secara lengkap pada lembar lampiran 1.

Hasil Analisa Perhitungan Hubungan BCS (Body Condition Score) dengan Tingkat Keberhasilan IB dengan Menggunakan Rumus Pearson Product Moment

Rumus korelasi Pearson digunakan untuk mengetahui hubungan antara dua variabel yang memiliki data berskala interval/rasio.

Tabel 3. Hasil penelitian dari perhitungan rumus Pearson

\begin{tabular}{|l|l|l|l|l|l|}
\hline $\mathrm{N}$ & $\Sigma \mathrm{x}$ & $\Sigma \mathrm{y}$ & $\Sigma \mathrm{x}^{2}$ & $\Sigma \mathrm{y}^{2}$ & $\Sigma \mathrm{xy}$ \\
\hline 30 & 56 & 82 & 108 & 241 & 140 \\
\hline
\end{tabular}

Nilai korelasi (r) dihitung dengan rumus Pearson adalah - 0,02 jadi $-1 \leq-0.02 \leq+1$ yang berarti $\mathrm{Ho}=$ diterima tidak ada hubungan antara BCS (Body Condition Score) dengan NRR (Non Return Rate). Kemudian diuji dengan menggunakan uji t Parsial, hasil dari uji t Parsial $=-0,10585, \mathrm{dk}=\mathrm{n}-2=30-2=28 . \alpha=0,5, \mathrm{~T}$ tabel $=2,763$, jika nilai $-0,10585$ berada ditengah mendekati 0 antara $-2,763$ ditolak dan 2, 763 ditolak maka nilai korelasi berarti diterima. Data lengkap tentang perhitungan rumus Pearson bisa dilihat pada lembar lampiran 2.

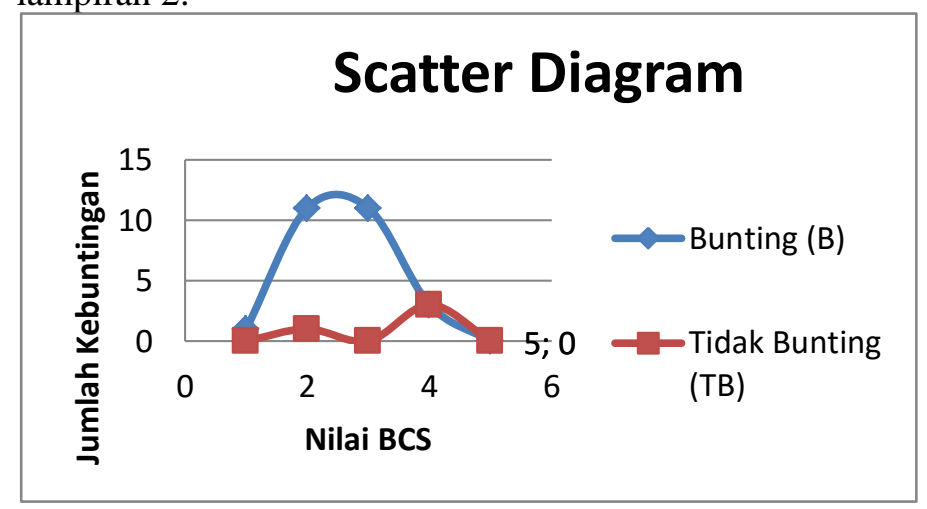

Gambar 2. Grafik hasil penelitian

Keterangan :

Untuk BCS nilai 1 jumlah kebuntingan 1 dan tidak bunting 0 , BCS nilai 2 jumlah kebuntingan 11 dan tidak bunting 1 , BCS nilai 3 jumlah kebuntingan 11 dan tidak bunting 0 , BCS nilai 4 jumlah kebuntingan 3 dan tidak bunting 3 , dan BCS nilai 5 jumlah kebuntingan 0 dan tidak bunting 0 . 


\section{Pembahasan}

Hasil dari penelitian ini menunjukkan bahwa untuk keberhasilan IB yang paling banyak yaitu pada tingkat BCS 1 dan 3 ditinjau dari jumlah tingkat BCS dan keberhasilan yang paling banyak terjadi.

Berikut jumlah keberhasilan IB sesuai dengan tingkat BCS dan jumlah keberhasilan IB yang dicapai :

- BCS 1 jumlah ternak $1=$ kebuntingan 1 ekor

- $\quad$ BCS 2 jumlah ternak $12=$ kebuntingan 11 ekor

- $\quad$ BCS 3 jumlah ternak $11=$ kebuntingan 11 ekor

- BCS 4 jumlah ternak $6=$ kebuntingan 3 ekor

- BCS 5 jumlah ternak $0=$ kebuntingan 0 ekor

Untuk tingkat BCS 1 dari 1 ekor sapi terjadi kebuntingan 1 dikarenakan faktor turunan dari tetua yang mempunyai jarak interval yang baik walaupun ditinjau dari keadaan tubuh sapi kurang baik.

Pada tingkat BCS 2 dari 12 ekor sapi terjadi kegagalan hanya 1 , faktor penyebabnya adalah pengetahuan peternak tentang berahi kurang.

Pada tingkat BCS 3 dari 11 ekor sapi terjadi kebuntingan 11, dikarenakan ke 4 faktor yang berpengaruh terhadap keberhasilan IB terpenuhi.

Pada tingkat BCS 4 dari 6 ekor sapi terjadi keberhasilan 3 dan kegagalan 3, kegagalan terjadi karena terdapat penimbunan lemak pada saluran reproduksi.

Hal-hal tersebut diatas sesuai dengan teori yang dikemukakan oleh Toelihere (1997), bahwa keberhasilan suatu inseminasi pada ternak ditentukan oleh 4 faktor utama, yaitu 1.Semen beku, 2.Ternak betina sebagai akseptor IB, 3. Keterampilan tenaga pelaksana (Inseminator) dan 4. Pengetahuan zooteknis peternak.

Sesuai data tersebut diatas juga bisa disimpulkan secara ringkas bahwa antara tingkat BCS dan keberhasilan IB tidak berpengaruh atau tidak ada hubungan/tidak berkorelasi yang artinya bila nilai BCS naik nilai tingkat keberhasilan IB tidak ikut naik begitu juga sebaliknya bila nilai BCS menurun belum tentu tingkat keberhasilan IB ikut menurun.

Menurut Aditya Budiawan, dkk (2015) dalam penelitiannya yang berjudul Hubungan Body Condition Score Terhadap Service Per Conception dan Calving Interval Sapi Potong Peranakan Ongole Di Kacamatan Babat Kabupaten Lamongan, hubungan antara BCS (X) dengan S/C (Y) memiliki persamaan regresi $\mathrm{Y}=0,88+0,06 \mathrm{X}$. Artinya dengan bertambahnya BCS 1 poin maka nilai $\mathrm{S} / \mathrm{C}$ bertambah sebesar $0,06 \%$. Nilai koefisien determinasinya (R2) sebesar $1,6 \%$ artinya nilai tersebut menunjukkan bahwa BCS memberikan konstribusi 1,6\% terhadap nilai $\mathrm{S} / \mathrm{C}$ atau nilai $\mathrm{S} / \mathrm{C}$ hanya $1,6 \%$ yang dipengaruhi oleh BCS dan 98,4\% dipengaruhi oleh faktor lain. Nilai keeratan atau koefisien korelasi (r) sebesar 0,12 (sangat rendah) artinya BCS memiliki keeratan yang rendah dengan $\mathrm{S} / \mathrm{C}$ hal ini sesuai dengan hasil dari penelitian ini bahwa nilai BCS (Body Condition Score) tidak mempengaruhi terhadap keberhasilan suatu IB (Inseminasi Buatan).

\section{Kesimpulan}

\section{KESIMPULAN DAN SARAN}

Berdasarkan hasil penelitian perhitungan korelasi dengan menggunakan rumus Pearson bahwa nilai korelasi (r) adalah - 0, 02. Nilai hitung uji t Parsial - 0, 10585 sedangkan uji t tabel 2, 763. Menurut Pearson (1995), apabila nilai koefisien korelasi mendekati 0 (Nol) berarti pasangan data Variabel $\mathrm{X}$ dan Variabel $\mathrm{Y}$ memiliki korelasi yang lemah atau kemungkinan tidak berkorelasi.

Dalam penelitian ini dapat disimpulkan bahwa nilai BCS (Body Condition Score) sapi potong tidak berpengaruh terhadap keberhasilan suatu Inseminasi Buatan (IB).

\section{Saran}

Berdasarkan penelitian yang telah dilakukan, saran peneliti adalah sebagai berikut :

1. Bagi penelitian selanjutnya agar dapat meneliti hubungan antara BCS dengan keberhasilan IB lebih spesifikasi lagi mengenai jenis ras dan umur sapi (Akseptor).

2. Bagi peternak agar lebih memperhatikan lagi tentang pemeliharaan calon sapi 
indukan / indukan (Akseptor) supaya dapat

memaksimalkan reproduksi ternak mereka.

\section{DAFTAR PUSTAKA}

Blakely, J dan David, H. D. 1994. Ilmu Peternakan. Gajah Mada University Press. Yogyakarta.

Budiawan A, dkk. 2015. Hubungan Body Condition Score Terhadap Service Per Conception dan Calving Interval Sapi Potong Peranakan Ongole Di Kacamatan Babat Kabupaten Lamongan. J. Ternak Tropika Vol. 16, No.1: 34-4.

Edmonson AJ, Lean IJ, Weaver LD, Loid JW, Farver T, Webster G. 1989. A Body Condition Scoring Chart for Holstein dairy cows. J Dairy Sci. 72: 68-70.

Feradis.2010. Bioteknologi Reproduksi pada Ternak. Bandung. Alfabeta.

Harjosubroto W, Astuti JM. 1993. Buku Pintar Peternakan. Jakarta (ID) : Grasindo.

Hafez, E.S.E. 1993. Artificial insemination. In: HAFEZ, E.S.E. 1993. Reproduction in Farm Animals. 6 Th Ed. Lea \&Febiger, Philadelphia. pp. 424-439.

Murtidjo, B. A. 1993. Beternak Sapi Potong. Kanisius.Yogyakarta.

Mozes R, Toelihere, Drh., M. Sc., Dr. 1979. Fisiologi Reproduksi Pada Ternak. Angkasa. Bandung.

Nuryadi dan S. Wahjuningsih. 2011. Penampilan Reproduksi Sapi Peranakan Ongole dan Peranakan Limousin di Kabupaten Malang. Jurnal Ternak Tropika 12, Vol 1:7681.

Pammusureng. 2009. Penilaian kondisi tubuh dan pengukuran pertumbuhan pedet \& dara. Bahan presentasi KPSBU Lembang.

Partodiharjo, S. 1992. Buletin Reproduksi

Hewan. Mutiara. Jakarta. Salisbury, G, W, and Van Demark. 1961. Physiology of Reproduction and Artificial Insemination of Cattle. TerjemahDjanuar, R. 1985.
Rianto, Edy dan Purbowati, Endang. 2009. Panduan lengkap Sapi Potong. Penebar Swadaya, Semarang.

Rasjid, Sjamsuddin, Prof., Dr., Ir,. H. 2011. The Great Ruminant, Nutrisi, Pakan, dan Manajemen Produksi. Brilliant Internasional. Surabaya.

Syaifudin, Arif. 2013. Profil Body Condition Score (BCS) Sapi Perah di Wilayah Koperasi Peternakan Sapi Bandung Utara (KSPBU) Lembang. Bandung.

Sudarmono, dan Y. Bambang Sugeng. 2008. Sapi Potong Edisi Revisi. Penebar Swadaya. Semarang.

Setiadi, Mohammad Agus, E. Gumbira Sa'id dan R. Kurnia Achjadi. 2012. Sapi Dari Hulu ke Hilir dan Info Mancanegara. Agriflo. Jakarta.

Siregar, 2002.S.B. 2002. Penggemukan Sapi. PenebarSwadaya. Jakarta.

Sugeng, B. Y. 2003. Sapi Potong.PenebarSwadaya. Jakarta.

Sugiono. 2013. Metode Penelitian Kuantitatif Kualitatif dan R\&D. Alfabeta.Bandung.

Sugoro, Irwan. 2009. Pemanfaatan Inseminasi Buatan (IB) Untuk Peningkatan Produktivitas Sapi. Sekolah Ilmu dan Teknologi Hayati Institut Terknologi Bandung.

Toelihere, M. R. 1981.Fisiologi Reproduksi pada Ternak. PT.Angkasa Bandung.

Toelihere, M. R. 1977. Inseminasi Buatan pada Ternak. PT.Angkasa Bandung.

Walpore, R.E. 1995. Pengantar statistik, Edisi ke 3. Jakarta. Ramedia. 